\title{
ANALISIS PENENTUAN HARGA POKOK PRODUKSI PADA USAHA WARKOP CELEBES DI MOROWALI SULAWESI TENGAH
}

\author{
Penulis \\ RIKAYANTI \\ 18179223 \\ E-mail \\ Rikhayanti228@gmail.com \\ Institut Bisnis dan Keuangan Nitro Makassar
}

\begin{abstract}
ABSTRAK
Penelitian ini bertujuan untuk menganilisis harga pokok produksi kopi susu, Creamy Latte dan Es Kopi pada warkop Celebes dengan metode variabel costing. Penelitian ini dilakukan pada Usaha Warkop Celebes yang berlokasi di jalan Trans Sulawesi kabupaten Morowali, kecamatan Bungku Tengah,Sulawesi Tengah. Waktu penelitian yang diperlukan kurang lebih 1 bulan dengan menggunakan jenis data kuantitatif, berupa laporan biaya produksi Usaha warkop Celebes periode tahun 2021. Sumber data yang digunakan dalam penelitian ini adalah data sekunder yaitu data yang diperoleh secara langsung pada objek penelitian berupa laporan biaya produksi Usaha warkop Celebes dari periode tahun 2021 dan teknik pengumpulan yang menggunakan penelitian pustaka (Library research) teknik penelitian lapangan (Field Research.
\end{abstract}

Kata Kunci: harga pokok, produksi, Usaha Warkop Celebes.

\section{PENDAHULUAN}

\section{A. LATAR BELAKANG}

Kopi sebagai salah satu minuman yang banyak digemari dalam masyarakat. Keberadaanya sudah tidak asing lagi. Komsumsi kopi di dunia mencapai $70 \%$ berasal dari spesies kopi Arabika dan $26 \%$ berasal dari spesies kopi Robusta. Kopi merupakan salah satu komoditi perkebunan yang mempunyai peran penting dalam Kegiatan perekonomian di Indonesia. Hal ini dikarenakan kopi telah memberikan partisipasi yang cukup besar pada pendapatan devisa Negara, menjadi ekspor non migas, selain itu dapat menjadi penyedia lapangan kerja dan sumber penghasilan bagi petani kopi di Indonesia (Rahardjo:2012).

Seiring dengan berkembangnya dunia usaha saat ini, setiap perusahaan 
harus dapat mempertahankan keunggulan produknya dalam menghadapi persaingn global sehingga perusahaan tetap memiliki nilai tersendiri bagi masyarakat, seperti produk kopi dari Usaha warkop balla kopi by daeng yang saat ini tetap mempertahankan eksistensi kualitas dan tetap dikenal masyarakat, baik itu masyarakat lokal maupun internasioanal. Usaha warkop celebes telah berhasil memperkenalkan spesies kopi Arabika dari Sulawesi selatan khususnya dari kota Makassar, hal ini dapat dibuktikan dari kegiatan impor sesame provinsi kopi yang tetap dilakukan sampai saat ini.

Mengingat perkembangan produksi kopi saat ini, penetapan harga pokok produksi adalah hal yang sangat penting karena dapat memberikan banyak keuntungan. Diantaranya memberikan informasi harga pokok produksi yaitu untuk menetapkan harga jual produk, pemantauan penggunaan biaya produksi, perhitungan laba rugi berkala serta penentuan harga pokok persediaan barang jadi dan barang dalam proses yang akan disampaikan dalam laporan keuangn berupa neraca.Penetapan harga pokok produksi merupakan hal yang sangat penting bagi perusahaan, karena ketepatan penentuan harga pokok produk mempengaruhi ketepatan harga jual, sebab itu harga pokok harus dihitung dan ditentukan secara tepat sehingga harga jual menjadi tepat pula. Harga pokok produksi dapat ditentukan dengan beberapa metode diantaranya metode full costing dan metode variable costing.

Biaya produksi adalah sebuah pengeluaran yang dikeluarkan untuk menghasilkan sebuah macam produk tertentu melalui beberapa proses produksi pada sebuah perusahaan. Jumlah seluruh biaya produksi yang dikeluarkan untuk menghasilkan suatu jenis produk adalah pengeluaran yang sangat berarti pada suatu perusahaan karena memiliki pengaruh langsung pada keberlangsungan hidup perusahaan.

Usaha warkop celebes merupakan perusahaan yang bergerak dibidang industri pengolahan minuma siap saji yang berdisir sejak tahun 2016, terdapat beberapa produk yang menjadi produk usaha warkop , diantaranya kopi susu, creame latte, es kopi. Produk paling diminati konsumen yang ada di daerah Kabupaten Morowali yaitu produk kopi susu karena rata-rata konsumen berumur remaja sampai dengan orang tua. Dalam perkembangnnya, Usaha warkop celebes memiliki beberapa jenis kopi yaitu kopi susu yang dihasilkan dari teknik khusus dengan cara seduh kopi Arabika sebanyak $40 \mathrm{ml}$ kedalam cangkir, kemudian tuang susu dingin kedalam perangkat pembuat kopi dan panaskan hingga berbusa. Tambahkan $20 \mathrm{ml}$ susu panas kedalam 
kopi setalah itu letakan 2 sendok milk foam diatasnya sehingga menghasilkan rasa asam dan manis yang seimbang dengan aroma yang lembut dan segar.

\section{B. RUMUSAN MASALAH}

Berdasarkan uraian latar belakang diatas, maka rumusan masalah penulis mengambil adalah "Berapa Harga Pokok Produksi Kopi Susu, Creamy Latte dan Es Kopi pada Warkop Celebes dengan metode Variabel Costing?".

\section{TUJUAN PENELITIAN}

Adapun tujuan dari penelitian ini yaitu untuk menganilisis harga pokok produksi kopi susu, Creamy Latte dan Es Kopi pada warkop Celebes dengan metode variabel costing.

\section{KEGUNAAN PENELITIAN}

Kegunaan dalam penelitian ini

1) Bagi perusahaan

Dapat memberikan masukan dan gambaran bagi perusahaan dalam pengambilan keputusan mengenai penerapan harga pokok produksi dengan metode variabel costing.

2) Bagi peneliti sendiri

Penelitian ini merupakan implementasi dari ilmu khususnya akuntansi biaya yang telah di dapatkan selama proses pembelajaran.

3) Peneliti selanjutnya yaitu dapat menjadikan pertimbangan dan masukan serta menambah wawasan serta informasi bagi mereka yang ingin mengadakan penelitian selanjutnya.

\section{KAJIAN PUSTAKA}

\section{Akuntansi Biaya}

Akuntansi secara umum adalah proses pencatatan, penggolongan, peringkasan, dan penyajian dengan caracara tertentu dari transaksi keuangan yang terjadi, sedangkan biaya dalam pengertian yang luas merupakan pengorbanan yang telah terjadi atau mungkin akan terjadi untuk mencapai tujuan tertentu. Menurut Wijakson (2013:3) mengatakan bahwa akuntansi biaya merupakan satu dari bagian disiplin ilmu dalam akuntansi. Secara sederhana akuntansi biaya dapat diartikan dari istilanya sebagai akuntansi yang khusus digunakan dalam pengukuran dan pelaporan biaya

$$
\text { Menurut Mulyadi }
$$
akuntansi biaya adalah proses pencatatan, penggolongan, peringksan, dan penyajian biaya pembuatan dan penjualan produc atau jasa dengan ideide tertentu, serta penafsiran terhadapnya. Sedangkan Supriono (2011:12) akuntansi biaya ialah salah satu cabang akuntansi yang merupakan alat manajemen dalam memonitor dan merekam transaksi biaya secara sistematik,serta memberikan informasi biaya dalam bentuk laporan biaya. 


\section{Tujuan Akuntansi Biaya}

Mulyadi (2016:7), mengemukakan bahwa akuntansi biaya mempunyai tiga tujuan pokok, yaitu 1) menentukan kos producsi. Untuk mencukupi tujuan penentuan kos producsi, akuntansi biaya mencatat, menggolongkan, dan meringkas biaya-biaya pembuatan produk atau penyerahan jasa, 2) Pengendalian biaya. Pengendalian biaya harus diawali dengan penentuan biaya yang seharusnya dikeluarkan untuk memproduksi satu satuan produk, jika biaya ini yang seharusnya ditetapkan, akuntansi biaya bertugas untuk mementau apakah pengeluaran biaya yang sesunggunya sesuai dengan biaya yang seharusnya, 3) Pengambilan keputusan khusus. Pengambilan keputusan khusus berhubungan dengan masa.

Sedangkan menurut Ahmad dan Abdullah (2012:4), tujuan akuntansi biaya yaitu 1) penetapan harga pokok. Dalam menetapkan harga pokok, biaya-biaya himpunan menurut pekerjaan (job), bagian-bagian (departemen), atau dirinci lagi menurut pusat-pusat biaya, produk dan jasa, 2) perencanaan biaya. Perencanaan merupakan suatu usaha untuk merumuskan tujuan dan penyususnan program operasional yang lengkap dalam mewujudkan tujuan tersebut, termasuk pula proses penentuan strategi yang disusun untik jangkapanjang dan jangka pendek, 3) pengendalian biaya. Pengendalian merupakan usaha manajemen untuk mencapai tujuan yang telah diterapkan dengan melakukan perbandingan secara terus menerus antara perencanaan dengan rencana, 4) dasar untuk pengambilan keputusan.
Akuntansi biaya memberikan informasi biaya berbeda agae dapat dibandingkan dengan pendapatan (revenue) dari berbagai tindakan alternative yang akan dipilih oleh managemen seharusnya. 5) Pengambilan keputusan khusus, Pengambilan keputusan khusus berhubungan dengan masa yang akan datang. Oleh sebab itu informasi yang sesuai dengan pengambilan keputusan khusus selalu berhubungan dengan informasi yang akan datang. Informasi biaya ini tidak dicatat dalam catatan akunsansi biaya, melainkan suatu proses peramalan.

Menurut Ahmad dan Abdullah (2012:4), tujuan akuntansi biaya yaitu sebagai berikut 1) penetapan harga pokok, biaya-biaya himpunan menurut pekerjaan (job), bagianbagian (departemen), atau dirinci lagi menurut pusat-pusat biaya, produk dan jasa. 2) Perencanaan biaya, merupakan suatu usaha untuk merumuskan tujuan dan penyususnan program operasional yang lengkap dalam mewujudkan tujuan tersebut, termasuk pula proses penentuan strategi yang disusun untik jangkapanjang dan jangka pendek. 3) Pengendalian biaya, merupakan usaha manajemen untuk mencapai tujuan yang telah diterapkan dengan melakukan perbandingan secara terus menerus antara

Menurut Iryanie dan Handayani (2019:1) memiliki beberapa tujuan diantaranya:

a Penentuan HPP: mencatat, menggolongkan dan meringkas biaya pembuatan produk.

b. Menyediakan informasi biaya untuk kepentingan manajemen: biaya sebagai 
ukuran efisiensi.

C. Alat perencanaan: perencanaan bisnis pasti berkaitan dengan penghasilan dan biaya, perencanaan biaya akan memudahkan dalam mengendalikan biaya.

d. Memperkenalkan berbagai metode: berbagai macam metode dalam akuntansi biaya dapat dipilih sesuai dengan kepentingan yang diperlukan dengan hasil yang paling efektif dan afisien.

e. Pengambilan keputusan khusus: sebai alat manajemen dalam mengawasi dan merekam transaksi biaya secara sistematis dan menyajikan informasi biaya dalam bentuk laporan biaya.

f. Menghitung laba perusahaan pada periode tertentu: untuk mengetaui laba maka diperlukan biaya yang dikeluarkan, biaya merupakan salah satu komponen dalam laba.

g. Menghitung dan menganalisis ketidakefektifan dan tidaefisienan: membahas batas maksimum nan menentukan solusi terbaik jika ada perbedaan antara batas maksimum tersebut dengan sesungguhnya terjadi.

\section{Fungsi Akuntansi Biaya}

Menurut Muchlis (2013:5) rancangan akuntansi biaya diperlukan untuk aktivitas pengelompokkan, analisis dan pengumpulan mengenai pengeluaran, sehingga pembahasan akuntansi biaya dapat dijadikan patokan dalam penyusunan laporan biaya. Menurut Horngren (2008:45) harga pokok produksi (cost of goods manufactured) adalah ialah biaya barang yang dibeli untuk diproses sampai selesai, baik sebelum maupun selama periode akuntansi berjalan. Menurut Cecily dan Michael (2011) harga pokok produksi adalah total produksi barang-barang yang telah selesai dikerjakan dan ditranfer ke dalam persediaan barang jadi selama satu periode.

\section{Harga Pokok Produksi}

Menurut Horngren (2008:45) harga pokok produksi (cost of goods manufactured) adalah ialah biaya barang yang dibeli untuk diproses sampai selesai, baik sebelum maupun selama periode akuntansi berjalan.

Menurut Cecily dan Michael (2011) harga pokok produksi adalah total produksi barang-barang yang telah selesai dikerjakan dan ditranfer ke dalam persediaan barang jadi selama satu periode, sedangkan menurut Carter (2009:40), harga pokok produksi terdiri dari tiga elemen biaya, yaitu 1) bahan baku langsung, 2) tenaga kerja langsung, 3) Overhead pabrik.

\section{Tujuan Penetapan Harga Pokok Produksi}

Tujuan penetapan harga pokok produksi menurut Mulyadi (2010:7) yaitu 1) dengan diketahuinya harga pokok produksi, maka perusahaan dapat jaga menetapkan harga jual producnya. Selain itu, manajemen juga harus mempertimbangkan factor-faktor lain yang 
berperan dalam penentuan harga jual produc.

Seperti keaadaan pasar dan campur tanagn pemerintah. 2) Memantau realisasi biaya produksi, manajemen membutuhkan informasi biaya produksi yang sesunggunya dikeluarkan dalam pelaksanaan rencana produksi. Untuk akuntansi biaya dapat digunakan untuk mengumpulkan informasi biaya produksi yang dikeluarkan dalam jangka waktu tertentu untuk memantau apakah proses produksi mengkonsumsi total biaya produksi sesuai dengan anggaran diperhitungkan sebelumnya. Pengumpulan biaya produksi untuk jangka waktu tertentu tersebut dengan menggunakan harga pokok proses.

\section{Unsur-unsur Biaya Produksi}

Mulyadi (2010:275) menjelaskan pengertian bahan baku merupakan bahan yang membentuk bagian menyeluruh produk jadi. Bahan baku yang diolah dalam perusahaan manufaktur dapat diperoleh dari pembelian local, impor atau dari pengolahan sendiri. Didalam memperoleh bahan baku, perusahaan tidak hanya mengeluarkan biaya sejumlah harga beli bahan baku saja, tetapi juga mengeluarkan biaya-biaya pembelian, pergudangan dan biaya-biaya perolehan lain.

Menurut Daljono (2005:15) biaya tenaga kerja (BTK) adalah gaji atau upah karyawan bagian produksi. Biaya ini dibebankan menjadi biaya tenaga kerja langsung dan biaya tenaga kerja tidak langsung. Gaji atau upah tenaga kerja yang dipekerjakan untuk memperoleh bahan menjadi barang jadi adalah biaya tenaga kerja langsung. (BTKL), sedangkan biaya gaji atau upah tenaga kerja bagian produksi yang tidak terlibat secara langsung dalam proses pengerjaan bahan menjadi produk jadi merupakan tenaga kerja tidak langsung (BTK). Menurut Mursyidi (2010:213) tenaga kerja dapat digolongkan menjadi dua, yaitu biaya tenaga kerja langsung (direct labor) biaya tenaga kerja langsun $g$ berhubungan dengan proses producsi, misalnya tukang dan pekerja pabrik. Biaya tenaga kerja tidak langsung (indirect labor), merupakan biaya tenaga kerja yang tidak langsung berhubungan dengan proses produksi, misalnhya gaji direktor produksi, pengawas, dan administrasi produksi. Menurut Bustami dan Nurlaela (2010:12), biaya tenaga kerja langsung merupakan tenaga kerja yang digunakann dalam mengubah atau mengonversi bahan baku menjadi produk selesai dan dapat ditelusuri secara langsung kepada produk selesai. Berdasarkan pendapat para ahli tersebut maka dapat disimpulkan bahwa tenaga kerja adalah factor penting berupa sumberdaya manusia yang mempengaruhi proses pengelolaan bahan bakumenjadi barang jadi pada suatu proses produksi dan biaya tenaga kerja adalah uapah yang diberikan kepada tenaga kerja bagi usaha tersebut.

Menurut Daljono (2005:15) biaya overhead pabrik (factory overhead cost) adalah biaya yang timbul dalam proses produksi selain yang termasuk dalam biaya bahan baku dan biaya tenaga kerja langsung. Menurut Garisson (2006) biaya overhead pabrik merupakan pengumpulan seluruh biaya produksi yang tidak termasuk dalam bahan langsung dan tenaga kerja langsung. Sedangkan menurut Supriono (2011), biaya 
overhead pabrik adalah biaya produksi selain biaya bahan baku dan biaya tenaga kerja langsung, yang elemennya dapat digolongkan kedalam biaya bahan penolong, biaya tenaga kerja tidak langsung, penyusutan dan amortisasi aktiva tetap pabrik, biaya asuransi pabrik, dan biaya overhead lain-lain.

\section{Metode penetapan harga pokok produksi}

Metode perhitungan harga pokok produksi merupakan cara memperhitungkan unsur biaya produksi kedalam harga pokok produksi. Dalam memperhitungkan unsurunsur biaya kedalam harga pokok produksi terdapat dua pendekatan, yaitu: full costing dan variable costing. Perbedaan pokok antara kedua metode tersebut terdapat pada perilaku terhadap biaya produksi yang bersifat tetap dan akan berakibat pada perhitungan harga pokok produksi dan penyajian laporan laba rugi.

Unsur-unsur penetapan biaya pada harga pokok produksi ada dua, yaitu: metode full costing dan variable costing.

\section{1) Harga pokok penuh (full costing)}

Samryn (2001), full costing adalah metode penentuan harga pokok yang memperhitungkan semua biaya produksi yang terdiri dari biaya bahan baku, biaya tenaga kerja, dan biaya overhead pabrik tanpa memperhitungkan perilakunya.

Mulyadi (2012:17), mengemukakan bahwa, full costing merupakan metode penentuan cost produksi yang memperhitungkan semua unsur biaya produksi kedalam cost produksi, yang terdiri dari biaya bahan baku, biaya tenaga kerja langsung, dan biaya overhead pabrik, baik yang berperilaku variabel atau tetap.

Menurut Mulyadi (2005;18), metode full costing terdiri dari unsur biaya produksi sebagai berikut:

Biaya bahan baku $\operatorname{Rp} x x x$

Biaya overhead pabrik variabel $\mathrm{Rp} x \mathrm{xx}$

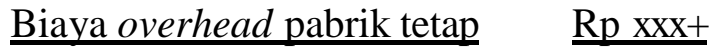
Harga pokok produksi $\quad$ Rp xxx

Biaya overhead pabrik dibedakan kepada pruduk atas dasar tarif yang ditetapkan diawal pada kapasitas normal, maka jika dalam suatu periode biaya overhead pabrik sesunggunya berbeda dengan yang dibebankan tersebut, akan terjadi pembebanan overhead lenih ( overapplied factory overhead) atau pembebanan overhead kurang (underapplied factory overhead), jika semua produk yang diolah dalam periode tersebut belum laku terjual, maka pembebanan biaya overhead lebih atau kurang tersebut digunakan untuk mengurangi atau menambahkan harga pokok produk yang masih dalam persediaan baik yang berupa persedian dalam proses atau pun barang jadi, namun jika dalam satu periode akuntansi tidak terjadi pembebanan overhead lebih atau kurang, maka biaya overhead pabrik tetap tidak mempunyai pengaruh terhadap perhitungn laba rugi sebelum produk laku terjual, jadi biaya overhead pabrik yang terjadi, baik yang 
berperilaku tetap maupun variabel masih dianggap sebagai aktiva karena melekat pada persediaan sebelum persediaan tersebut terjual.

\section{2) Harga Pokok Variabel (Variable costing)}

Mulyadi (2012:18) mengemukakan bahwa, variable cosring merupakan metode penetapan cost priduksi yang hanya memperhitungkan biaya produksi yang berperilaku variabel kedalam cost produksi, yang terdiri dari biaya bahan baku, biaya tenaga kerja langsung, dan biaya overhead pabrik variabel. Samryn (2001) variable costing adalah suatu format laporan laba rugi yang mengelompokan biaya dimana biaya-biaya dipisahkan menurut kategori biaya variabel dan biaya tetap dan tidak dipisahkan menurut fungsi-fungsi produksi, administrasi, dan penjualan. Sunarto (2009) mengemukakan bahwa, variable costing adalah penentuan harga pokok produksi dengan memperhitungkan biaya priduksi yang bersifat variabel dalam harga pokok produksi, yang terdiri dari bahan baku, biaya tenaga kerja langsung, dan overhead pabrik. Biaya produksi yang bersifat tetap variable costing diperlukan sebagai biaya periode akuntansi dimana biaya tersebut terjadi. Dari pengertian diatas dapat ditarik kesimpulan bahwa unsur harga pokok produksi menurut metode ini meliputi:

Biaya bahan baku $\operatorname{Rp} x x x$ Biaya tenaga kerja langsung $\quad \mathrm{Rp} x x x$
Biaya overhead pabrik variabel $\mathrm{Rp} \mathrm{xxx}$ Harga pokok produksi $\quad$ Rp xxx

Pengertian harga pokok variable costing merupakan metode penentuan harga pokok produksi yang hanya memperhitungkan biaya produksi yang berperilaku variabel kedalam harga pokok produksi yang terdiri dari bahan baku, biaya tenaga kerja langsung, dan biaya overhead pabrik.

\section{Manfaat penentuan harga pokok produksi}

Menurut Mulyadi (2015:17) metode penentuan kos (biaya) produksi adalah cara memperhitungkan unsur-unsur biaya kedalam kos (biaya) produksi. Dalam perhitungan unsur-unsur biaya kedalam biaya produksi terdapat dua pendekatan yaitu full costing dan variable costing. full costing merupakan metode penentuan biaya produksi yang memperhitungkan semua unsur biaya produksi kedalam kos produksi, yang terdiri dari biaya bahan baku, biaya tenaga kerja langsung, dan biaya overhead pabrik baik yang berperilaku variabel maupun tetap.

Dengan demikian kos produksi menurut metode full costing terdiri dari unsur biaya produksi berikut ini:

Biaya bahan baku $\quad \mathrm{Xx}$

Biaya tenaga kerja langsung $\mathrm{Xx}$

Biaya overhead pabrik variabel Xx

Kos produksi Xx

Biaya produk yang dihitung dengan pendekatan full costing terdiri dari kos produksi (biaya bahan baku, biaya tenaga kerja langsung, biaya overhead pabrik 
variabel, biaya overhead tetap) ditambah dengan biaya non produksi (biaya pemasaran, biaya administrasi dan umum).

Menurut Mulyadi (2015:18) variable costing merupakan metode panentuan kos produksi yang hanya memperhitungkan biaya produksi yang berperilaku variabel kedalam kos produksi, yang terdiri dari biaya bahan baku, biaya tenaga kerja langsung dan biaya overhead pabrik variabel.

Dengan demikian kos produksi menurut metode variable costing terdiri dari unsur biaya produksi berikut ini:

$\begin{array}{ll}\text { Biaya bahan baku } & \mathrm{Xx} \\ \text { Biaya tenaga kerja langsung } & \mathrm{Xx} \\ \text { Biaya overhead pabrik variabel } & \underline{\mathrm{Xx}} \\ \text { Biaya overhead pabrik tetap } & \mathrm{Xx} \\ \text { Kos produksi } & \mathrm{Xx}\end{array}$

Kos produk yang diprhitungkan dengan pendekatan variable costing terdiri dari unsur kos produksi variabel (biaya bahan baku, biaya tenaga kerja langsung, dan biaya overhead pabrik variabel) ditambah dengan biaya non produksi variabel (biaya pemasaran variabel, biaya administrasi dan umum variabel) dan biaya tetap (biaya overhead pabrik tetap, biaya pemasaran tetap, biaya administrasi dan umum tetap).

Mulyadi mengemukakan (2016:65), dalam perusahaan yang memproduksi massa, informasi harga pokok produksi yang dihitung dalam jangkan waktu tertentu berguna bagi manajemen untuk:

a. Menetapkan harga jual produk, perusahaan yang memproduksi massa memproses produknya untuk memenuhi persediaan digudang.

b. Memantau penggunaan biaya produksi, Jika rencana produksi untuk jangka waktu tertentu telah diputuskan untuk dilakukan, manajemen membutuhkan informasi pengeluaran produksi yang sebenarnya dikeluarkan didalam melakukan Kegiatan produksi tersebut.

c. Menghitung laba rugi periodic. Untuk mengetahui apakah aktivitas produksi dan pemasaran perusahaan dalam waktu tertentu mampu menciptaakan keuntungan bruto atau mengakibatkan rugi bruto, manajemen menciptakan informasi biaya produksi yang telah dikeluarkan untuk membuat produk dalam waktu tertentu.

d. Menentukan harga pokok persediaan produk jadi dan produk dalam proses yang dimasukan dalam neraca.

\section{Perilaku Konsumen}

Daga, R. (2013: 29) dalam journal progresif jurnal, 2013 menjelaskan tentang perilaku konsumen merupakan segala sesuatu yang mempengaruhi seseorang dalam memutuskan suatu hal, perilaku ini dipengaruhi oleh factorfaktor yang bersifat internal dan eksternal factor internal konsumen itu sendiri yang meliputi usia konsumen, pekerjaan 
konsumen, keadaan ekonomi konsumen, gaya hidup seseorang, motivasi dalam menggunakan sesuatu, persepsi terhadap suatu produk, kepercayaan dan sikap konsumen terhadap produk yang dibutuhkan, dengan harapan produk yang dibutuhkan tersebut adalah produk yang berkualitas sehingga bias digunakan oleh konseumen (Irwan dan Haryono, 2015). Sedangkan factor eksternal adalah adalah factor yang mendorong seseorang dari luar konsumen itu sendiri yaitu kebutuhan seseorang, kelas social konsumen, factor yang mempengaruhi di luar keluarga dan lingkungannya yaitu referensi dari atasan atau teman (Daga, 2017).

\section{METODOLOGI PENELITIAN}

\section{A. Lokasi Dan Waktu Penelitian}

Penelitian ini dilakukan pada Usaha warkop Celebes yang berlokasi di jalan Trans Sulawesi kabupaten Morowali, kecamatan Bungku Tengah,Sulawesi Tengah. Waktu penelitian yang diperlukan kurang lebih 1 bulan.

\section{B. Jenis Dan Sumber Data}

Penelitian ini menggunakan jenis data kuantitatif, berupa laporan biaya produksi Usaha warkop Celebes periode tahun 2021. Sedangkan sumber data yang digunakan dalam penelitian ini adalah data sekunder yaitu data yang diperoleh secara langsung pada objek penelitian berupa laporan biaya produksi Usaha warkop Celebes dari periode tahun 2021.

\section{Teknik Pengmpulan Data}

Pada teknik pengumpulan data dalam penelitian ini menggunakan penelitian pustaka (Library research). Penelitian pustaka ( Library research) adalah informasi yang diperoleh dengn memperoleh referensi, menbaca bukubuku literatur dan karya ilmiah yang berkaitan dengan topik penelitian ini. Kemudian menggunakan teknik penelitian lapangan (Field Research), yaitu penelitian yang dilakuakn untuk memperoleh data langsung dari objeknya. Diteliti dengn tujuan untuk memperoleh data sekundar berupa data laporan keuangn Usaha warkop Celebes tahun 2021.

\section{Populasi Dan Sampel}

Populasi dalam penelitian ini adalah laporan biaya produksi Usaha warkop Celebes pada tahun sedangkan sampel yang digunakan dalam penelitian ini adalah sampel jenuh yaitu seluruh laporan boiaya produksi pada tahun 2021.

\section{E. DEFINISI OPERASIONAL}

a. Harga pokok produksi merupakan penjumlahan seluruh pengorbanan sumber ekonomi yang digunakan untuk mengubah bahan baku menjadi satu produk. 
b. Biaya bahan baku adalah bahan dasar yang digunakan dalam proses produksi sampai produk jadi seperti kopi susu.

c. Biaya tenaga kerja langsung adalah balas jasa yang diberikan kepada karyawan produksi baik yang secara langsung maupun yang tidak langsung turut ikut mengerjakan produksi barang yang berhubungan.

d. Biaya overhead pabrik adalah pengeluaran yang tidak bisa diberikan langsung pada sebuah hasil produksi. Biaya ini meliputi biaya - biaya selain bahan baku dan biaya tenaga kerja langsung.

e. Full costing adalah metode penentuan harga pokok produksi yang dengan membebankan seluruh biaya dalam proses produksi.

\section{F. Analisis Data}

Analisis data yang digunakan dalam penelitian ini adalah analisis deskriptif kuantitatif, yaitu data-data yang berhibungan dengan biaya produksi untuk menghitung harga pokok produksi dengan metode analisis yang dapat memberikan uraian jelas mengenai suatu keadaan atau fenomena. Dengan rumus yang akan digunakan sebagai berikut :

Bahan baku biaya $\quad$ Rp xxx Biaya overhead pabrik langsung $\mathrm{Rp} x \mathrm{xx}$ Biaya overhead pabrik variabel $\underline{\mathrm{Rp} x x x}$ Harga pokok produksi $\quad \mathrm{Rp} x \mathrm{xx}$

\section{DAFTAR PUSTAKA}

Ahmad, Abdulla,2012. Akuntansi Biaya, Edisi 3. Selemba Empat.

Bustami, B dan Nurlaela, 2010. Akuntansi Biaya, Yogyakarta: Graha ilmu.

Carter, Wiliiamk, 2009. Akuntansi Biaya, Edisi empat belas. Jakarta: salemba empat.

Cecily A Raiborn dan Michael R. Kinney. 2011. Akuntansi Biaya, dasar dan perkembangan, buku 1 edisi 7. Jakarta: salemba empat.

Daga, R. 2017. Citra, Kualitas Produk dan Kepuasan Pelanggan . Makassar: Global Research and Consulting Institute

Garrison Ray H 2006. Akuntansi Manejerial, Jakarta: salemba empat. Horngren, Charles. 2008. Akuntansi Biaya: pendekatan Manejerial, Jakarta: Erlangga.

Halim, Kusumo dan Kusufi. 2013. Akuntansi Manajemen: Akuntansi 
Manejerial, Edisi kedua. Yogyakarta: BPFE.

Mulyadi, 2012. Akuntansi Biaya, edisi kelima. Yogyakarta: Unit Penerbit dan Percetakan Akademi Manajemen Perusahaan YPKN.

Muchlis, Saiful. 2013. Akuntansi Biaya Kontemporer, Makassar: alauddin University.

Mursyidi 2010. Akuntansi Biaya, Bandung:

PT. Refika Aditama.

Rahardjo, p. 2012. Panduan Budidaya dan

Pengolahan Kopi Arabika dan

Robusta. Depok: Penerbit Penebar

Swadaya

Supriono. 2011. Akuntansi Biaaya

Pengumpilan Biaya dan Penentuan

Harga Pokok, buku satu, edisi dua.

Cetakan dua belas, Yogyakarta: BPFE.

Samryn, L. M. 2001. Akuntansi

Manajerial. Jakarta: PT Raja

Grafindo Persada.

Sunarto. 2009. Akuntansi Biaya.

Yogyakakarta: AMUS Yogyakarta.

Wijaksono, Armanto. Akuntansi Biaya.

Yogyakarta: Graha Ilmu. 